\title{
Effect of Salinity on Photosynthesis and Distribution of Photosynthates in the Japanese Tomato 'CF Momotaro York' and the Dutch Tomato 'Endeavour' with Low Node-order Pinching and a High-density Planting System
}

\author{
Kazuya Maeda ${ }^{1}$, Masahumi Johkan ${ }^{1}$, Satoru Tsukagoshi²* and Toru Maruo ${ }^{1}$ \\ ${ }^{1}$ Graduate School of Horticulture, Chiba University, Matsudo 271-8510, Japan \\ ${ }^{2}$ Center for Environment, Health and Field Sciences, Chiba University, Kashiwa 277-0882, Japan
}

In this study, we investigated the effect of salinity on photosynthesis and the distribution of photosynthates in the Japanese tomato (Solanum lycopersicum) cultivar 'CF Momotaro York' and the Dutch cultivar 'Endeavour'. Although significant differences were not observed in fresh yield among the cultivars, there were significant differences between the control and salinity in terms of fresh yield, total soluble solids, and titratable acid. The total dry weight in the Japanese cultivar was not affected by salinity, but the Dutch cultivar had lower total weight under salinity compared to the control. Regarding dry mass partitioning, the Japanese cultivar had a lower dry mass ratio of vegetative organs and a higher ratio of fruits than the Dutch cultivar. Salinity did not affect the photosynthetic rate in the Japanese cultivar, but did affect the Dutch cultivar, possibly due to water use efficiency. These results indicate that this Japanese cultivar has characteristics of efficient fruit production under a low node-order pinching and high-density planting system, even under salinity conditions.

Key Words: dry matter partitioning, dry weight, gas exchange, salt stress, water use efficiency.

\section{Introduction}

Dutch tomato cultivars have been bred with an emphasis on yield using a long-term and high-wire training system. The production of tomatoes in the Netherlands is $508,379 \mathrm{~kg} \cdot \mathrm{ha}^{-1}$, whereas it is $61,433 \mathrm{~kg} \cdot \mathrm{ha}^{-1}$ in Japan, which is $88 \%$ lower than the Netherlands according to FAOSTAT, 2017 (http://faostat.fao.org/site/ 567/default.aspx\#ancor, November 5, 2019). In order to clarify the reason for the high yield of Dutch tomato cultivars, many investigations have been conducted to compare the characteristics of Japanese and Dutch cultivars (Matsuda et al., 2011a, b, 2013; Higashide et al., 2014). However, these studies were conducted under a high-wire training system and comparatively sparse planting density. Dutch tomato cultivars have lower light extinction coefficients than Japanese cultivars (Higashide and Heuvelink, 2009), indicating that the Japanese cultivars could not reach their production potential under these conditions.

Received; November 18, 2019. Accepted; March 29, 2020.

First Published Online in J-STAGE on May 26, 2020.

* Corresponding author (E-mail: tsukag@faculty.chiba-u.jp).
Japanese tomato cultivars, on the other hand, have been bred with an emphasis on quality (Higashide and Heuvelink, 2009), and breeding selection is conducted under soil conditions that are susceptible to various environmental stresses, including water stress. The cultivation method mainly focuses on relatively short plant heights, such as picking the meristem at the $6^{\text {th }}$ to $8^{\text {th }}$ stages, or continuous pinching cultivation. In recent years, a low-node and high-density planting system has attracted attention as a unique Japanese cultivation system for stable production (Lu et al., 2012; Johkan et al., 2013; Kinoshita et al., 2014; Tewolde et al., 2016). This system could enable selection of tomato cultivars throughout the year and reduce the risk of disease and pest incidence. In particular, it is easy to combine with salt stress treatment to produce tomatoes with high sugar content (Sakamoto et al., 1999; Saito et al., 2006; Johkan et al., 2014).

Salinity stress enhances tomato fruit quality by increasing the amount of total soluble acids, including sugars, amino acids, and organic acids (Adams, 1991; Saito et al., 2008) and it also affects photosynthesis and dry matter partitioning (Ho et al., 1987; Saito et al., 2009). However, the effect of salt stress differed among 
some tomato cultivars (Alfocea et al., 1993). In fact, Inada et al. (2016) showed that the reason for growth reduction by root restriction in terms of water stress between the Japanese and Dutch tomato cultivars was different, indicating that the effect of salinity may be different between these cultivars.

There have been many experiments comparing Japanese and Dutch tomato cultivars with a focus on the yield achieved under the Dutch cultivation system. However, there is limited information comparing these cultivars under the Japanese cultivation system, especially under salt stress conditions. Therefore, in this experiment, we compared Japanese and Dutch tomato cultivars under a low node-order pinching and highdensity planting system with salt or non-salt conditions and identified the characteristics of these cultivars.

\section{Materials and Methods}

\section{Plant material and growth conditions}

Two tomato cultivars (the Japanese cultivar ' $\mathrm{CF}$ Momotaro York'; Takii \& Co., Ltd., Kyoto, Japan, and the Dutch cultivar 'Endeavour'; Rijk Zwaan, De Lier, the Netherlands) were used. The experiment was conducted in a greenhouse (north-south oriented) at the Kashiwanoha campus of Chiba University from August 18 to December 25, 2018.

The seeds were sown in a cell tray filled with commercial substrate (Na-Terra; Mitsubishi Chemical Agri Dream Co., Ltd, Tokyo, Japan). The substrate consisted of vermiculite, peat moss and red clay soil and seeds were germinated in a growth chamber maintained at $30^{\circ} \mathrm{C}$. Immediately after germination, the seedlings were moved to a chamber set to a light/dark period of $14 / 10 \mathrm{~h}$, light/dark temperature of $23 / 18^{\circ} \mathrm{C}, \mathrm{a} \mathrm{CO}_{2}$ concentration of $1,000 \mu \mathrm{mol} \cdot \mathrm{mol}^{-1}$ and light intensity of $300 \mu \mathrm{mol} \cdot \mathrm{m}^{-2} \cdot \mathrm{s}^{-1}$ and were raised for three weeks. The seedlings were then transplanted individually in $0.5 \mathrm{~L}$ pots with a restricted root zone filled with a mixture of coconut fiber and rice husks ( $\mathrm{v} / \mathrm{v}=7: 3)$, and the pots were placed in a nutrient film hydroponic system with north-south oriented gutters. The seedlings were fertilized by a drip system using Enshi nutrient solution. The solution consisted of $16.0 \mathrm{me} \cdot \mathrm{L}^{-1} \mathrm{NO}_{3}^{-}, 1.3 \mathrm{me} \cdot \mathrm{L}^{-1}$ $\mathrm{NH}_{4}^{+}, \quad 8.0 \mathrm{me} \cdot \mathrm{L}^{-1} \quad \mathrm{~K}^{+}, \quad 8.0 \mathrm{me} \cdot \mathrm{L}^{-1} \quad \mathrm{Ca}^{2+}, 4.0 \mathrm{me} \cdot \mathrm{L}^{-1}$ $\mathrm{Mg}^{2+}, 4.0 \mathrm{me} \cdot \mathrm{L}^{-1} \mathrm{H}_{2} \mathrm{PO}_{4}^{-}, 3.0 \mathrm{ppm} \mathrm{Fe}, 0.5 \mathrm{ppm} \mathrm{Mn}$, $0.5 \mathrm{ppm} \mathrm{B}, 0.05 \mathrm{ppm} \mathrm{Zn}, 0.02 \mathrm{ppm} \mathrm{Cu}$, and $0.01 \mathrm{ppm}$ Mo, adjusted to an electrical conductivity (EC) of $2.4 \mathrm{dS} \cdot \mathrm{m}^{-1}$. All lateral branches were removed, and the shoot tip was pinched to retain three leaves above the first inflorescence. In addition, flowers were sprayed with a commercial hormonal solution (Tomato Tone; ISK Biosciences K.K., Tokyo, Japan) when the fourth flower in the inflorescence opened to enhance fruit set.

\section{Salinity treatment}

In the control treatment, the EC was set at $1.2 \mathrm{dS} \cdot \mathrm{m}^{-1}$ after the seedlings were transplanted, and was main- tained until the end of cultivation. In the salinity treatments, an EC of $6.0 \mathrm{dS} \cdot \mathrm{m}^{-1}$ was supplied one week after the hormonal solution. The drained solution from the bottom of the pot was recycled, and the nutrient solution was reset once a week. Ten plants per treatment were transplanted and this was replicated twice at 6.7 plants $\cdot \mathrm{m}^{-2}$.

\section{Leaf gas-exchange and water use efficiency}

The photosynthetic rate, transpiration rate, and stomatal conductance of fully expanded leaves just above the first truss were measured between 10:00 and 11:30 AM with an LI-6400 portable photosynthesis system (Li-Cor Inc., Lincoln, NE, USA). Measurements were made at a leaf cuvette air temperature of $23^{\circ} \mathrm{C}$, PPFD of $\quad 1,000 \mu \mathrm{mol} \cdot \mathrm{m}^{-2} \cdot \mathrm{s}^{-1}, \quad \mathrm{CO}_{2}$ concentration of $400 \mu \mathrm{mol} \cdot \mathrm{mol}^{-1}$, and relative humidity of $60-70 \%$. The measurements were repeated three times. The water use efficiency (WUE) was calculated by dividing the photosynthetic rate by the transpiration rate (Nobel, 1991).

\section{Fruit yield and quality analyses}

The fruit was harvested 104 days after transplantation, and fresh weight was measured. The sugar content and acidity were measured using a non-destructive sugar acidity meter (K-BA100R-1; Kubota Corporation, Osaka, Japan), and then placed in a dryer set at $90^{\circ} \mathrm{C}$ for 10 days, after which the fruit dry weight was measured.

\section{Plant growth analyses}

The stem length, stem diameter, leaf area, and SPAD value of the same leaves during leaf gas-exchange were measured after harvesting. Then, six plants from each treatment were randomly selected for destructive harvesting. Each plant shoot was divided into leaves and stem parts, and the materials were oven-dried at $80^{\circ} \mathrm{C}$ for three days before measuring the dry weight. The roots, including the pots and substrate, were oven-dried at $80^{\circ} \mathrm{C}$ for 10 days, and then the total weight of each pot and substrate was measured. Finally, the pot and substrate weight were subtracted.

\section{Statistical analysis}

Results were analyzed with XLSTAT software (Esmi Co., Tokyo, Japan). All data were analyzed using the Student's $t$-test and two-way ANOVA. Differences were considered significant when $P<0.05$.

\section{Results}

The Dutch cultivar had a significantly longer stem length, higher LAI, and SPAD values, but lower SLA compared to the Japanese cultivar (Table 1). There were significant $(P<0.05)$ differences in stem diameter, LAI, and SPAD values between the control and salinity conditions, and a significant interaction effect of cultivar $\times$ salinity on the SPAD value $(P<0.001)$. For each 
cultivar, no significant differences in the stem length and SLA under different conditions were observed. The stem diameter and SPAD values of the Japanese cultivar under salinity were higher compared to the control.

There were significant differences among the cultivars; the Japanese cultivar had higher levels of total soluble solids and a lower level of titratable acid than the Dutch cultivar (Table 2). There was no significant difference in fresh yield between the cultivars. There were significant differences between the control and salinity in fresh yield, total soluble solids, and titratable acid $(P<0.001)$. Salinity reduced the yield of the Japanese and Dutch cultivars by $23 \%$ and $32 \%$, respectively.

There was no significant difference in the total dry weight of the cultivars (Table 3). Regarding dry mass partitioning, the Japanese cultivar had a lower dry mass ratio of vegetative organs and a higher ratio of fruits than the Dutch cultivar. There were significant differences between the control and salinity in terms of total dry weight and the root ratio $(P<0.05)$. The total dry weight of the Japanese cultivar was not affected by salinity, but the Dutch cultivar had a lower total dry weight under salinity compared to the control. The ratio of roots was higher in both cultivars under salinity com-

Table 1. Stem length, stem diameter, LAI, SLA and SPAD values of Japanese and Dutch cultivar grown under salt and non-salt condotions and low-node order pinching with high density cultivation.

\begin{tabular}{ccccccc}
\hline \hline Cultivar & Environment & Stem length $(\mathrm{cm})$ & Stem diameter $(\mathrm{mm})$ & LAI $\left(\mathrm{m}^{2} \cdot \mathrm{m}^{-2}\right)$ & SLA $\left(\mathrm{cm}^{2} \cdot \mathrm{g}^{-1}\right)$ & SPAD value \\
\hline \multirow{2}{*}{ 'CF Momotaro York' } & Control & $78.4 \pm 0.9 \mathrm{a}^{\mathrm{z}}$ & $9.9 \pm 0.9 \mathrm{~b}$ & $1.8 \pm 0.03 \mathrm{a}$ & $141 \pm 3.6 \mathrm{a}$ & $35.8 \pm 0.8 \mathrm{~b}$ \\
& Salinity & $79.0 \pm 1.2 \mathrm{a}$ & $10.7 \pm 1.2 \mathrm{a}$ & $1.7 \pm 0.09 \mathrm{a}$ & $136 \pm 3.1 \mathrm{a}$ & $43.1 \pm 1.0 \mathrm{a}$ \\
\hline \multirow{2}{*}{ 'Endeavour' } & Control & $128.9 \pm 1.0 \mathrm{~A}$ & $9.9 \pm 1.0 \mathrm{~A}$ & $2.2 \pm 0.10 \mathrm{~A}$ & $130 \pm 7.0 \mathrm{~A}$ & $43.1 \pm 1.0 \mathrm{~A}$ \\
& Salinity & $131.2 \pm 0.8 \mathrm{~A}$ & $10.3 \pm 0.8 \mathrm{~A}$ & $1.8 \pm 0.08 \mathrm{~B}$ & $117 \pm 4.9 \mathrm{~A}$ & $42.4 \pm 0.6 \mathrm{~A}$ \\
\hline \multirow{3}{*}{ Significance } & Cultivar & $* * *$ & $\mathrm{NS}$ & $* *$ & $*$ & $* *$ \\
& Environment & $\mathrm{NS}$ & $*$ & $*$ & $\mathrm{NS}$ & $* *$ \\
& Interaction & $\mathrm{NS}$ & $\mathrm{NS}$ & $\mathrm{NS}$ & $\mathrm{NS}$ & $* * *$ \\
\hline
\end{tabular}

${ }^{z}$ Values withn a colum followed by a significantly different value for the same cultivar $(P<0.05$; by Student's $t$-test).

${ }^{y} \mathrm{NS}, * * *$, and $* * *$ indicate not significant or significantly differences of $P<0.05,0.01$, and 0.001 by two-way ANOVA.

Table 2. Fresh weight, total soluble solids, and titratable acid of Japanese and Dutch cultivar grown under salt and non-salt condotions and lownode order pinching with high density cultivation.

\begin{tabular}{|c|c|c|c|c|}
\hline Cultivar & Environment & Total yield (g/plant) & Total soluble solids (Brix\%) & Titratable acid $(\%)$ \\
\hline \multirow{2}{*}{ 'CF Momotaro York' } & Control & $832 \pm 28.7 \mathrm{a}^{\mathrm{z}}$ & $5.8 \pm 0.1 \mathrm{~b}$ & $0.31 \pm 0.01 \mathrm{~b}$ \\
\hline & Salinity & $643 \pm 29.4 \mathrm{~b}$ & $6.9 \pm 0.1 \mathrm{a}$ & $0.39 \pm 0.02 \mathrm{a}$ \\
\hline \multirow{2}{*}{ 'Endeavour' } & Control & $824 \pm 17.0 \mathrm{~A}$ & $5.3 \pm 0.1 \mathrm{~B}$ & $0.34 \pm 0.01 \mathrm{~B}$ \\
\hline & Salinity & $562 \pm 10.2 \mathrm{~B}$ & $6.3 \pm 0.1 \mathrm{~A}$ & $0.44 \pm 0.01 \mathrm{~A}$ \\
\hline \multirow{3}{*}{ Significance ${ }^{\mathrm{y}}$} & Cultivar & NS & $* * *$ & $* * *$ \\
\hline & Environment & $* * *$ & $* * *$ & $* * *$ \\
\hline & Interaction & NS & NS & NS \\
\hline
\end{tabular}

${ }^{z}$ Values withn a colum followed by a significantly different value for the same cultivar $(P<0.05$; by Student's $t$-test).

y NS and *** indicate not significant or significantly differences of $P<0.001$ by two-way ANOVA.

Table 3. Total dry weight and fraction of dry weight partitioned to leaves, stem, fruit, and root of Japanese and Dutch cultivar grown under salt and non-salt condotions and low-node order pinching with high density cultivation.

\begin{tabular}{|c|c|c|c|c|c|c|}
\hline \multirow{2}{*}{ Cultivar } & \multirow{2}{*}{ Environment } & \multirow{2}{*}{$\begin{array}{l}\text { Total dry weight } \\
\text { (g/plant) }\end{array}$} & \multicolumn{4}{|c|}{ Dry mass partitioning (\%) } \\
\hline & & & Leaf & Stem & Fruit & Root \\
\hline \multirow{2}{*}{ 'CF Momotaro York' } & Control & $99.6 \pm 3.9 \mathrm{a}^{\mathrm{z}}$ & $19.6 \pm 0.7 \mathrm{a}$ & $9.5 \pm 0.3 \mathrm{a}$ & $64.7 \pm 0.6 \mathrm{a}$ & $6.1 \pm 0.2 \mathrm{~b}$ \\
\hline & Salinity & $97.1 \pm 4.1 \mathrm{a}$ & $19.8 \pm 0.3 \mathrm{a}$ & $8.9 \pm 0.4 \mathrm{a}$ & $63.8 \pm 1.1 \mathrm{a}$ & $7.6 \pm 0.5 \mathrm{a}$ \\
\hline \multirow{2}{*}{ 'Endeavour' } & Control & $109.8 \pm 4.4 \mathrm{~A}$ & $23.6 \pm 0.7 \mathrm{~A}$ & $13.2 \pm 0.5 \mathrm{~A}$ & $56.1 \pm 1.5 \mathrm{~A}$ & $7.1 \pm 0.7 \mathrm{~B}$ \\
\hline & Salinity & $96.1 \pm 3.5 \mathrm{~B}$ & $24.3 \pm 1.0 \mathrm{~A}$ & $12.6 \pm 0.3 \mathrm{~A}$ & $52.6 \pm 0.8 \mathrm{~A}$ & $10.5 \pm 0.7 \mathrm{~A}$ \\
\hline \multirow{3}{*}{ Significance $^{y}$} & Cultivar & NS & $* * *$ & $* * *$ & $* * *$ & $* *$ \\
\hline & Environment & $*$ & NS & NS & NS & $* * *$ \\
\hline & Interaction & NS & NS & NS & NS & NS \\
\hline
\end{tabular}

z Values withn a colum followed by a significantly different value for the same cultivar $(P<0.05$; by Student's $t$-test).

${ }^{y} \mathrm{NS}, * * *$, and $* * *$ indicate not significant or significantly differences of $P<0.05,0.01$, and 0.001 by two-way ANOVA. 
Table 4. Photosynthetic rate, transpiration rate, stomatal conductance, and water use effeciency of Japanese and Dutch cultivar grown under salt and non-salt condotions and low-node order pinching with high density cultivation at 45, 59, and 73 days after transplanting (DAT).

\begin{tabular}{|c|c|c|c|c|c|c|c|c|c|c|c|c|c|}
\hline \multirow[t]{2}{*}{ Cultivar } & \multirow[t]{2}{*}{ Environment } & \multicolumn{3}{|c|}{$\begin{array}{l}\text { Photosynthetic rate } \\
\left(\mu \mathrm{mol} \mathrm{CO} 2 \cdot \mathrm{m}^{-2} \cdot \mathrm{s}^{-1}\right)\end{array}$} & \multicolumn{3}{|c|}{$\begin{array}{l}\text { Stomatal conductance } \\
\left(\mathrm{mol} \mathrm{H} \mathrm{H}_{2} \mathrm{O} \cdot \mathrm{m}^{-2} \cdot \mathrm{s}^{-1}\right)\end{array}$} & \multicolumn{3}{|c|}{$\begin{array}{l}\text { Transpiration rate } \\
\left(\mathrm{mmol} \mathrm{H} \mathrm{H}_{2} \mathrm{O} \cdot \mathrm{m}^{-2} \cdot \mathrm{s}^{-1}\right)\end{array}$} & \multicolumn{3}{|c|}{$\begin{array}{l}\text { Water use efficiency } \\
\qquad\left(\mathrm{mg} \cdot \mathrm{g}^{-1}\right)\end{array}$} \\
\hline & & 45 DAT & 59 DAT & 73 DAT & 45 DAT & $59 \mathrm{DAT}$ & 73 DAT & $45 \mathrm{DAT}$ & 59 DAT & 73 DAT & 45 DAT & 59 DAT & 73 DAT \\
\hline \multirow{2}{*}{ 'CF Momotaro York' } & Control & 14.7 & 10.9 & $7.4 a^{z}$ & $0.47 \mathrm{a}$ & $0.34 \mathrm{a}$ & $0.09 \mathrm{a}$ & $5.2 \mathrm{a}$ & $4.0 \mathrm{a}$ & $1.3 \mathrm{a}$ & 6.9 & $6.8 \mathrm{a}$ & $13.9 \mathrm{a}$ \\
\hline & Salinity & 13.2 & 11.5 & $6.5 \mathrm{a}$ & $0.36 \mathrm{~b}$ & $0.25 \mathrm{~b}$ & $0.09 \mathrm{a}$ & $3.8 \mathrm{~b}$ & $3.2 \mathrm{a}$ & $1.3 \mathrm{a}$ & 8.5 & $8.8 \mathrm{a}$ & $12.2 \mathrm{a}$ \\
\hline \multirow{2}{*}{ 'Endeavour' } & Control & 17.7 & 14.9 & $10.6 \mathrm{~A}$ & $0.54 \mathrm{~A}$ & $0.35 \mathrm{~A}$ & $0.23 \mathrm{~A}$ & $5.7 \mathrm{~A}$ & $4.5 \mathrm{~A}$ & $3.4 \mathrm{~A}$ & 7.6 & $8.2 \mathrm{~B}$ & $7.6 \mathrm{~B}$ \\
\hline & Salinity & 15.5 & 14.5 & $8.4 \mathrm{~B}$ & $0.41 \mathrm{~B}$ & $0.24 \mathrm{~B}$ & $0.14 \mathrm{~B}$ & $4.3 \mathrm{~B}$ & $3.0 \mathrm{~B}$ & $1.7 \mathrm{~B}$ & 8.8 & $11.9 \mathrm{~A}$ & $12.1 \mathrm{~A}$ \\
\hline \multirow{3}{*}{ Significance $^{\mathrm{y}}$} & Cultivar & * & $*$ & $* * *$ & NS & NS & $* * *$ & NS & NS & $* * *$ & NS & $*$ & $* * *$ \\
\hline & Environment & NS & NS & $*$ & $* *$ & $*$ & $* * *$ & $* * *$ & $*$ & $* *$ & $*$ & $* *$ & $*$ \\
\hline & Interaction & NS & NS & NS & NS & NS & $* * *$ & NS & NS & $* *$ & NS & NS & $* * *$ \\
\hline
\end{tabular}

z Values withn a colum followed by a significantly different value for the same cultivar $(P<0.05$; by Student's $t$-test).

y $\mathrm{NS}, *, * *$, and $* * *$ indicate not significant or significantly differences of $P<0.05,0.01$, and 0.001 by two-way ANOVA.

pared to the control.

The Dutch cultivar had a significantly higher photosynthetic rate than the Japanese cultivar at $45,59,73$ days after transplanting (DAT) and a higher stomatal conductance and transpiration rate at 73 DAT (Table 4). There were significant differences between the control and salinity in the photosynthetic rate at 73 DAT and the stomatal conductance and transpiration rate at 45 , 59,73 DAT $(P<0.05)$, and a significant interaction effect of cultivar $\times$ salinity on the stomatal conductance and transpiration rate at 73 DAT $(P<0.01)$. Salinity did not affect the photosynthetic rate in the Japanese cultivar, but did affect the Dutch cultivar at 73 DAT. The Dutch cultivar had a significantly higher WUE than the Japanese cultivar at 59 DAT, but this was significantly lower at 73 DAT. There were significant differences between the control and salinity in the WUE at 45, 59, 73 DAT, and a significant interaction effect of cultivar $\times$ salinity on WUE at 73 DAT $(P<0.01)$.

\section{Discussion}

The Japanese cultivars had the same or higher LAI than Dutch cultivars in previous studies (Higashide et al., 2014, 2017) compared to the two cultivars under the Dutch cultivation system. However, the Japanese cultivars had lower LAI than the Dutch cultivars (Table 1). Moreover, Saito et al. (2009) stated that salinity stress starting at first flower anthesis of the first truss reduced the total dry weight with high EC $\left(8.0 \mathrm{dS} \cdot \mathrm{m}^{-1}\right)$ under the NFT system and Zhai et al. (2016) indicated that LAI decreased as the salinity level increased with EC values of 1.0, 3.0, and $5.0 \mathrm{dS} \cdot \mathrm{m}^{-1}$ under hydroponic and soil culture. In this experiment, salinity treatment was started at the fourth flower anthesis of the first truss with an EC of $6.0 \mathrm{dS} \cdot \mathrm{m}^{-1}$. Therefore, the EC was lower and the duration was shorter than the previous study and the cultivation conditions were different so the present results did not coincide with previous studies.

In previous studies, Dutch tomato cultivars had higher yield than Japanese cultivars under Dutch cultivation systems (Higashide and Heuvelink, 2009; Higashide et al., 2014; Ando et al., 2015); however, there was no significant difference in yield between the Japanese and Dutch cultivars in the present study (Table 2), probably because the distribution rate of assimilation products into fruits was significantly lower in the Dutch cultivars $(P<0.001)$ (Table 3). The fruit distribution rate could be used as an indicator of sink strength (Ho, 1988). Matsuda et al. (2011a) and Nakano et al. (2012) indicated that Dutch cultivars have higher sink strength than Japanese cultivars under the Dutch cultivation system. However, the results of this experiment were not consistent with the previous studies. Moreover, Nakano et al. (2013) showed that the contribution of the roots to yield was low in relatively short-term cultivation, and that it is important to increase the accumulation of assimilation products in the parts above the ground. Therefore, the Japanese cultivar had characteristics suitable for efficient fruit production under a low nodeorder pinching and high-density planting system. Under salinity stress, the yield reduction rate was greater in the Dutch cultivar than in the Japanese cultivar (Table 2) and this was due to a reduction in the total dry weight caused by reduced LAI and photosynthesis (Tables 1 and 4). In fact, the LAI and photosynthesis in the Dutch cultivar were also affected by salinity.

In previous studies, Dutch cultivars had higher photosynthesis under a Dutch cultivation style (Higashide and Heuvelink, 2009; Saito et al., 2011; Matsuda et al., 2013) and there was the same tendency under a low node-order pinching and high-density planting system (Table 4). The photosynthesis in both cultivars decreased as growth progressed. Moreover, comparing the photosynthesis in the cultivars at 45 and 73 DAT with the control, the reduction was higher in the Japanese cultivar than in the Dutch cultivar by $50 \%$ and $40 \%$, respectively, and this was due to reduced stomatal conductance and leaf senescence. In fact, Saito et al. (2011) reported that the chlorophyll a and b content did not decrease in a Dutch cultivar compared with 
that in a Japanese cultivar at 50 days after flowering under a low node-order pinching and high-density planting system. However, the Japanese cultivar maintained the photosynthetic rate with low stomatal conductance at 73 DAT and this may have been due to the higher WUE. In fact, the values in the Japanese cultivar were significantly higher than those in the Dutch cultivar (Table 1). In salinity stress, no difference was observed in the Japanese cultivar, whereas in the Dutch cultivar, there was a significant decrease in 73 DAT. Moreover, the stomatal conductance and transpiration rate in the Dutch cultivar under salinity at 73 DAT significantly decreased and there was an interaction effect of cultivar $\times$ salinity. Therefore, the reduction in photosynthesis at 73 DAT in the Dutch cultivar may have been due to stomatal conductance and water absorption. On the other hand, photosynthesis could be maintained in the Japanese cultivar at 73 DAT possibly due to increased WUE.

In conclusion, the Dutch cultivar had a lower distribution rate of assimilation products into fruits under a low node-order pinching and high-density planting system and showed decreased LAI and photosynthesis with salinity, which induced a reduction in fruit yield. The photosynthesis decreased because of a reduction in stomatal conductance and lower WUE. On the other hand, the Japanese cultivar had a higher distribution rate into fruits. Moreover, the higher water use efficiency during the senescence process under salinity maintained the photosynthetic rate without a reduction in the total dry weight. These factors were considered to have contributed to the maintenance of fruit yield.

\section{Literature Cited}

Adams, P. 1991. Effects of increasing the salinity of the nutrient solution with major nutrients or sodium chloride on the yield, quality and composition of tomatoes grown in rockwool. Journal of Horticultural Science 66: 201-207.

Alfocea, F. P., M. T. Estan, M. Caro and M. C. Bolarin. 1993. Response of tomato cultivars to salinity. Plant Soil 150: 203211.

Ando, A., A. Nakano, S. Kaneko, R. Yokoyama, T. Higashide, M. Hatanaka and S. Kimura. 2015. Characteristics of taste components and fruit yields of Dutch and Japanese tomato cultivars. Bulletin of the National Institute of Vegetable and Tea Science 14: 31-38.

Higashide, T. and E. Heuvelink. 2009. Physiological and morphological changes over the past 50 years in yield components in tomato. J. Amer. Soc. Hort. Sci. 134: 460-465.

Higashide, T., Y. Mochizuki, T. Saito, Y. Kawasaki, D. Ahn and A. Ohyama. 2017. Differential influences of leaf tip trimming on light interception and dry matter production in tomato Dutch cultivar Gourmet and Japanese cultivar Momotaro York. HortScience 52: 686-691.

Higashide, T., A. Nakano and K. Yasuba. 2014. Yield and dry matter production of a Japanese tomato 'Momotaro York' are improved by grafting onto a Dutch rootstock 'Maxifort' J. Japan. Soc. Hort. Sci. 83: 235-243.

Ho, L. C. 1988. Metabolism and compartmentation of imported sugars in sink organs in relation to sink strength. Annual
Review of Plant Physiology and Plant Molecular Biology 39: $355-378$.

Ho, L. C., R. I. Grange and A. J. Picken. 1987. An analysis of the accumulation of water and dry matter in tomato fruit. Plant, Cell and Environment 10: 157-162.

Inada, H., M. Nakahara and T. Ueta. 2016. Differential responses of growth, transpiration and nutrient absorption properties between Japanese and Dutch cultivars of tomato to root restriction. Root Research 25: 29-36.

Johkan, M., M. Ishii, T. Maruo, N. Lu, S. Tsukagoshi, M. Hojoh, A. Nakaminami and Y. Shinohara. 2013. Improved light conditions at the fruit truss accelerate harvest time and enhance ascorbic acid concentration in a low-truss, highdensity tomato production system. J. Japan. Soc. Hort. Sci. 82: 317-321.

Johkan, M., A. Nagatsuka, A. Yoshitomi, T. Nakagawa, T. Maruo, S. Tsukagoshi, M. Hohjo, N. Lu, A. Nakaminami, K. Tsuchiya and Y. Shinohara. 2014. Effect of moderate salinity stress on the sugar concentration and fruit yield in singletruss, high-density tomato production system. J. Japan. Soc. Hort. Sci. 83: 229-234.

Kinoshita, T., T. Yano, M. Sugiura and Y. Nagasaki. 2014. Effects of controlled-release fertilizer on leaf area index and fruit yield in high-density soilless tomato culture using low nodeorder pinching. PLoS ONE 9: e113074. DOI: 10.1371/ journal.pone.0113074.

Lu, N., T. Maruo, M. Johkan, M. Hohjo, S. Tsukagoshi, Y. Ito, T. Ichimura and Y. Shinohara. 2012. Effects of supplemental lighting within the canopy at different developing stages on tomato yield and quality of single-truss tomato plants grown at high density. Environment Control in Biology 50: 1-11.

Matsuda, R., D. Ahn, A. Nakano, K. Suzuki and M. Takaichi. 2013. Leaf gas exchange characteristics of four Japanese and four Dutch tomato cultivars grown in a greenhouse. Sci. Hort. 156: 19-23.

Matsuda, R., A. Nakano, D. Ahn, K. Suzuki, K. Yasuba and M. Takaichi. 2011a. Growth characteristic and sink strength of fruit at different $\mathrm{CO}_{2}$ concentrations in Japanese and Dutch tomato cultivars. Sci. Hort. 127: 528-534.

Matsuda, R., K. Suzuki, A. Nakano, T. Higashide and M. Takaichi. 2011b. Response of leaf photosynthesis and plant growth to altered source sink balance in Japanese and Dutch tomato cultivar Sci. Hort. 127: 520-527.

Nakano, A., K. Kaneko, K. Yasuba, T. Higashide, K. Suzuki, S. Kimura and S. Tamura. 2013. Yield and root activity in tomatoes grown in a low-truss nutrient film technique under high-yielding conditions. Bulletin of the National Institute of Vegetable and Tea Science. 12: 75-80.

Nakano, A., R. Matsuda, M. Johkan, K. Suzuki, D. Ahn and M. Takaichi. 2012. Varietal difference of root development and starch accumulation on stem of tomato occurred by fruit thinning. Root Research 21: 39-43.

Nobel, P. S. 1991. Achievable productivities of certain CAM plants: Basis for high values compared with C-3 and C-4 plants. New Phytol. 19: 183-206.

Saito, T., N. Fukuda, C. Matsukura and S. Nishimura. 2009. Effects of salinity on distribution of photosynthates and carbohydrate metabolism in tomato grown using nutrient film technique. J. Japan. Soc. Hort. Sci. 78: 90-96.

Saito, T., N. Fukuda and S. Nishimura. 2006. Effects of salinity treatment duration and planting density on size and sugar content of hydroponically grown tomato fruits. J. Japan. Soc. Hort. Sci. 75: 392-398.

Saito, T., C. Matsukura, Y. Ban, K. Shoji, M. Sugiyama, N. Fukuda and S. Nishimura. 2008. Salinity stress affects as- 
similate metabolism at the gene-expression level during fruit development and improves fruit quality in tomato (Solanum lycopersicum L.). J. Japan. Soc. Hort. Sci. 77: 61-68.

Saito, T., Y. Yin, M. Matsuoka, S. Watanabe, C. Matsukura and N. Fukuda. 2011. An investigation of differences in fruit yield and components contributing to increased fruit yield in Japanese and Dutch tomato cultivars. Plant Biotechnology 28: 455-461.

Sakamoto, Y., S. Watanabe, T. Nakashima and K. Okano. 1999. Effects of salinity at two ripening stages on the fruit quality of single-truss tomato grown in hydroponics. J. Hort. Sci.
Biotech. 74: 690-693.

Tewolde, F. T., N. Lu, K. Shiina, T. Maruo, M. Takagaki, T. Kozai and W. Yamori. 2016. Nighttime supplemental LED interlighting improves growth and yield of single-truss tomatoes by enhancing photosynthesis in both winter and summer. Front. Plant Sci. 7: 448. DOI: 10.3389/fpls.2016. 00448.

Zhai, Y., Q. Yang and Y. Wu. 2016. Soil salt distribution and tomato response to saline water irrigation under straw mulching. PLoS ONE 11: e0165985. DOI: 10.1371/journal. pone. 0165985 . 